CANCER CELL

INTERNATIONAL

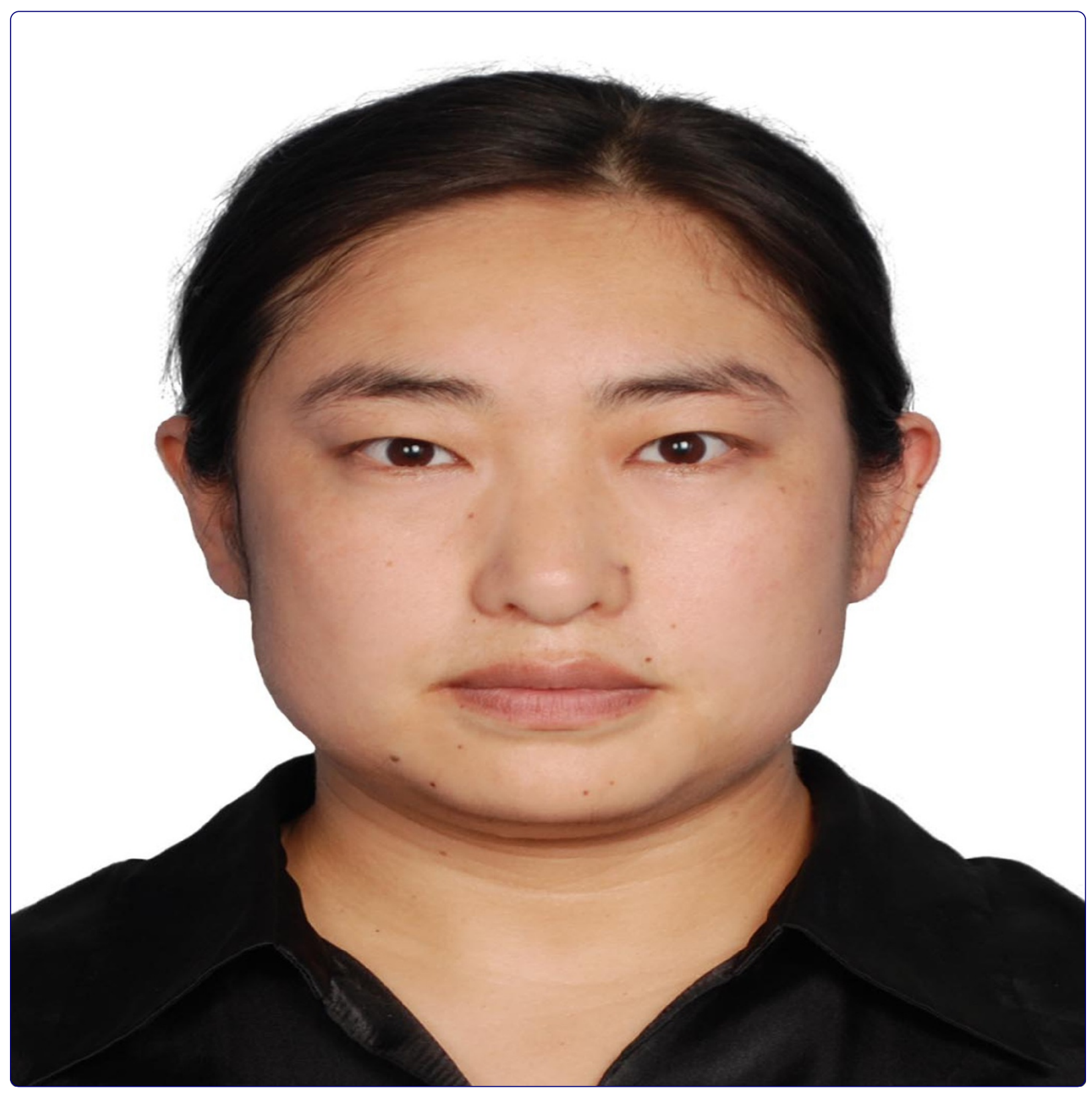

Association of integrin beta1 and c-MET in mediating EGFR TKI gefitinib resistance in non-small cell lung cancer

Ju and Zhou

() Biomed Central 


\title{
Association of integrin beta1 and c-MET in mediating EGFR TKI gefitinib resistance in non-small cell lung cancer
}

\author{
Lixia Ju ${ }^{1}$ and Caicun Zhou ${ }^{2^{*}}$
}

\begin{abstract}
Although some patients are initially sensitive to epidermal growth factor receptor tyrosine kinase inhibitors (EGFR TKIs), resistance invariably develops. Therefore, it's very important to study the molecular mechanism of this resistance. In our previous study we found that integrin beta1 can induce EGFR TKls resistance in non-small cell lung cancer (NSCLC) cells. Here we analyzed the association of integrin beta1 and c-MET that is a recognized mechanism of EGFR TKIs resistance in NSCLC to demonstrate the mechanism of integrin beta1 related EGFR TKIs resistance. We found that the ligands of integrin beta1 and c-MET could synergistically promote cell proliferation and their inhibitors could synergistically improve the sensitivity to gfitinib, increase apoptosis, and inhibit the downstream signal transduction: focal adhesion kinase (FAK) and AKT. On the other hand, ligand-dependent activation of integrin beta1 could induce EGFR TKIs resistance through activating c-MET and its downstream signals. Thus, it can be concluded that there is crosstalk between integrin beta1 and c-MET and integrin beta1 mediates EGFR TKI resistance associating with c-MET signaling pathway in non-small cell lung cancer.
\end{abstract}

Keywords: Non-small cell lung cancer, Integrin beta1, c-MET, EGFR TKI, Resistance

\section{Introduction}

The EGFR inhibitor gefitinib has been used as a single agent in NSCLC, but overall, the resistance remains a major problem clinicians encountered. Our previous result has shown that integrin beta1 overexpression associates with EGFR TKI resistance in PC9/AB2 cells [1]. In this study we further investigated the mechanism of integrin beta1-related EGFR TKI resistance.

Integrins and are formed by $\alpha$ and $\beta$ integrin subunits. There are at least 24 known heterodimers formed by 18 $\alpha$ and eight $\beta$ subunits. Natural integrin ligands include important components of the extracellular matrix (ECM). Beta1 subunit of integrin is an adhesion molecule involved in cell survival and cancer resistance to radiotherapy and chemotherapy [2-4], sharing common downstream signaling elements with EGFR, such as the

\footnotetext{
* Correspondence: caicunzhou@yahoo.com.cn

${ }^{2}$ Cancer Institute, Department of Oncology, Shanghai Pulmonary Hospital, Tongji University, Medical School, 507 Zhengmin Road, Shanghai 200433, China

Full list of author information is available at the end of the article
}

phosphatidylinositol 3-kinase/AKT and extracellular signal-regulated kinase-1/2 (ERK1/2) pathways [5-9].

The c-MET receptor is a $190-\mathrm{kD}$ disulfide linked $\alpha-\beta$ heterodimer [10]. and expressed in $60 \%-80 \%$ of NSCLC [11]. Unlike EGFR, the only known natural ligand for c-MET is hepatocyte growth factor (HGF, also known as scatter factor). Activation of c-MET can lead to proliferation, increased survival, altered motility, enhanced invasion into extracellular matrix, and more rapid formation of tubules [12]. On activation by autophosphorylation, c-MET can activate its multiple downstream signal transduction intermediates. Novel small molecule inhibitors of c-MET, SU11274 [13] and PHA-665752 [14] have shown to inhibit the phosphorylation of c-MET and the proliferation of cells in vitro.

In recent years, c-MET also has been found to be an independent biomarker of EGFR TKI resistance and about $21 \%$ acquired EGFR TKI resistance is caused by overexpression of c-MET [15]. Another research found that through promoting MET-integrin association, HGF-FN and HGF-VN complexes coordinated and enhanced endothelial cell migration through activation
Ciomed Central

(c) 2013 Ju and Zhou; licensee BioMed Central Ltd. This is an Open Access article distributed under the terms of the Creative Commons Attribution License (http://creativecommons.org/licenses/by/2.0), which permits unrestricted use, distribution, and reproduction in any medium, provided the original work is properly cited. 
of the PI-3 kinase pathway involving a Ras-dependent mechanism [16]. There is also an important crosstalk between c-MET and the integrin beta1 in mast cell: stimulation through $\mathrm{c}-\mathrm{MET}$ and the $\alpha 2 \beta 1$ integrin resulted in crosstalk between the two receptors, resulting in the activation of the mast cell leading to release of the pro-inflammatory cytokine, IL-6 [17]. Therefore, the crosstalk between integrin beta1 and c-MET may be also related with EGFR TKI resistance.

In present study, we investigated the relationship between integrin beta1 and c-MET in EGFR TKI resistance to explore the mechanism of EGFR TKI resistance in non-small cell lung cancer.

\section{Materials and methods Ethics approval}

All experiments were performed with the approved of the Tongji University Institutional Care and Use Committee (IACUC).

\section{Reagents and antibodies}

Human phospho-ERK antibody and human phospho-FAK antibody were purchased from Animal BioWorld Technology (Dublin, OH); human c-MET antibody, human phospho-AKT antibody, human phospho-c-MET antibody and human phospho-EGFR antibody were purchased from Cell Signaling Technology (Beverly, MA); $\beta$-actin antibody was purchased from ABGENT (San Diego, CA); human integrin beta1/CD29 antibody was purchased from R\&D Systems (Minneapolis, MN); IRDyeTM 800 Conjugated Affinity Purified Anti-mouse/rabbit Antibody was purchased from Rockland (Gilbertsville, PA).

\section{Cell lines and cell culture}

Human NSCLC cell line PC9 (harboring EGFR exon 19 deletion) was provided by Cancer Institute of Medical School, Tongji University, China [the original PC-9 cells were purchased from Immuno-Biological Laboratories (Takasaki, Gunma, Japan). The gefitinib-resistant NSCLC subline PC9/AB2 was induced from PC9 cells according to the method in the literature [18] and was continuously subcultured with $2 \mu \mathrm{mol} / \mathrm{L}$ of gefitinib for additional 6 months. The resistance of PC9/AB2 cells to gefitinib has been proved to maintain for at least one year in the medium without gefitinib and there is no T790M in PC9/AB2 [1]. PC9/AB2 cells were stablely transfected with integrin beta1-siRNA plasmid and scrambled siRNA plasmid and were named by AB2/172 and $\mathrm{AB} 2 / \mathrm{N}$ respectively; The integrin beta1 cDNA plasmid and the vacant vector were stablely transfected into PC9 cells and were named by PC9/D6, PC9/PCD respectively [1]. All these cells were cultured at $37^{\circ} \mathrm{C}$ with 5\% CO2 in Dulbecco's modified Eagle's medium
(DMEM) supplemented with 10\% fetal bovine serum (FBS), $100 \mathrm{U} / \mathrm{ml}$ penicillin and $100 \mathrm{mg} / \mathrm{ml}$ streptomycin.

\section{Western blot assay}

Cells were washed twice with ice-cold PBS and lysed in $0.1 \mathrm{ml}$ of lysis buffer on ice for $30 \mathrm{~min}$. Insoluble debris was removed by centrifuging at 13,000 rpm for $15 \mathrm{~min}$ at $4^{\circ} \mathrm{C}$. Electrophoresis and blotting procedures were done according to methods described previously. Primary antibodies against human integrin beta1/CD29, human cMET antibody, human phospho-EGFR and phospho-AKT, phospho-ERK1/2 and phospho-FAK were used according to the manufacturer's instructions. Blotting quantification was done with an Odyssey ${ }^{\circledR}$ Infrared Imaging system (LI-COR, USA).

\section{Fibronectin (FN) stimulate growth}

96-well plates were coated with or without fibronectin (FN) $20 \mu \mathrm{g} / \mathrm{ml} 100 \mu \mathrm{l}$. PC9, PC9/AB2 (5000/well) were plated in 96-well plates. After $24 \mathrm{~h}$, the wells were treated with or without HGF $50 \mathrm{ng} / \mathrm{ml}$, or treated with both of them in medium with $10 \%$ FBS. After $24 \mathrm{~h}$, viable cells were detected by MTT assays and cell viability was plotted as a mean $\pm \mathrm{SD}$ of three independent experiments. Percentage of cell viability was determined relative to the control that had no additional growth factors [19].

\section{Cell proliferation assay}

The cells $\left(5 \times 10^{3} /\right.$ well $)$ were seeded into 96 -well plate in quadruplicate and were exposed to various concentrations of gefitinib. After 72 hours, $20 \mu \mathrm{l}$ of 3 (4,5-diMEThylthiazol-2-yl)-2,5-diphenyltetrazolium bromide (MTT) solution $(5 \mathrm{mg} / \mathrm{ml})$ was added to each well and incubated. After 4 hours, crystalline formation was dissolved with Dimethyl sulfoxide (DMSO) and the absorbance at $530 \mathrm{~nm}$ was read using the microplate-reader for ELISA MK-2 Labsystems Dragon. The IC50 was defined as the concentration needed for a $50 \%$ reduction of the absorbance based on the survival curves. Percent survival was calculated as: (mean absorbance of the replicate wells containing drugs-mean absorbance of the replicate background wells) / (mean absorbance of the replicate drug-free wells-mean absorbance of the replicate background wells). The test was performed independently 3 times. All results were derived from quadruplicate experiments yielding almost similar results.

\section{Apoptosis assay}

Transferase-mediated deoxyuridine triphosphate nickend labeling (TUNEL) Kit (Promega, USA) were used for apoptosis assay. In TUNEL assay, cells were seeded in 24-well plates and exposed to gefitinib ( 5 or $15 \mu \mathrm{mol} / \mathrm{L}$ ) for another $48 \mathrm{~h}$. Then, apoptosis was assessed by the TUNEL assay kit (GENMED, China) following the 
manufacturer's protocol. Apoptotic index (AI) (\%) was calculated by the formula: positive staining cells/tumor cells number $\times 100 \%$.

\section{Statistical analyses}

Values were expressed as mean \pm SD. Statistical analysis was done by independent-samples $t$ test. Differences were considered to be statistically significant if $\mathrm{P}<0.05$.

\section{Results \\ Integrin beta1 and C-MET co-expressed in PC9 and PC9/ AB2 cell lines}

The expression of integrin betal and c-MET were determined by western blot. Integrin beta1 and c-MET were both expressed in the PC9 and PC9/AB2. Integrin beta1 expression was higher in $\mathrm{PC} / \mathrm{AB} 2$ than in $\mathrm{PC}$, and $\mathrm{c}-\mathrm{MET}$ expression was comparable in the two cell lines (Figure 1A).

\section{Fibronectin (FN) and HGF effect on the growth of PC9 and PC9/AB2 cell lines}

$\mathrm{FN}$ is the ligand of integrin betal and HGF is the ligand of c-MET. The effects of FN and HGF on cell growth were studied by treating cells with $20 \mu \mathrm{g} / \mathrm{ml} \mathrm{FN}$ or $50 \mathrm{ng} / \mathrm{ml}$ of HGF alone or in combination, and cell proliferation was determined by MTT as aforementioned. In PC9 and PC9/ AB2 cells, a synergistic proliferative effect was observed with a combination of FN and HGF (Figure 1B).

A synergistic effect can be defined as an effect that is more than the additive effect of FN and HGF alone. Combination Index $(\mathrm{CI})=(\mathrm{D}) 1 /(\mathrm{D} \mathrm{m}) 1+(\mathrm{D}) 2 /(\mathrm{D} \mathrm{m})$ 2 . Where (D) 1 and (D) 2 are the doses of chemicals 1 and 2 that in combination produce some specified effect (i. e. $50 \%$ inhibition of luminescence) and (D m) 1 and (D m) 2 are the doses of the chemicals that when applied singly also have the same effect (50\% inhibition of luminescence).

These results indicated that there was a synergistic proliferative effect of both ligands combined. Maybe because the level of integrin beta1 in PC9/AB2 cells is higher than that in PC9 cells, the synergistic effect of HGF and FN in PC9/AB2 cells is more evident than in PC9 cells. These results could be due to potential crosstalk between integrin beta1 and c-MET signaling pathways.

\section{Combination of integrin beta1-target siRNA and c-MET kinase inhibitor SU11274 synergized to inhibit proliferation of PC9/AB2 NSCLC cell line}

Since the synergistic proliferative effect of HGF and FN has been observed, we want to know whether the synergistic inhibition to cell growth can be found when we combined integrin beta1 siRNA with c-MET kinase inhibitor SU11274. The IC50 for each treatment was determined by MTT assay. The results shown that the
IC50 for gefitinib alone and the combination of SU11274 and gefitinib were $(24.2 \pm 5.45) \mu \mathrm{mol} / \mathrm{L}$ and $(7.34 \pm 2.84) \mu \mathrm{mol} / \mathrm{L}$ in $\mathrm{PC} 9 / \mathrm{AB} 2$ cells, respectively. Interestingly, a synergistic effect of gefitinib on inhibition of cell proliferation was seen in the presence of same dose of SU11274 in integrin beta1-inhibited AB2/ 17-2 cells. The IC50 for gefitinib alone in AB2/17-2 cells was $(1.9 \pm 1.28) \mu \mathrm{mol} / \mathrm{L}$, however the IC50 was $(0.26 \pm$ $0.15) \mu \mathrm{mol} / \mathrm{L}$ in the presence of same dose of SU11274 (Figure 1C). So, to inhibit the cells growth by $50 \%$, we need $30 \%$ or $8 \%$ of original gefitinib concentration respectively in presence of SU11274 or integrin beta1siRNA only. But we need only $1 \%$ of original gefitinib concentration when SU11274 and integrin beta1-target siRNA were combined. It suggested that combined inhibition of integrin beta1 and c-MET could improve effect of gefitinib in PC9/AB2 NSCLC cell line synergistically.

\section{Combination of integrin beta1-target siRNA and c-MET kinase inhibitor SU11274 induced apoptosis in a synergistic fashion}

TUNEL assay was performed to examine apoptosis. As shown in Figure 1D, the apoptosis rates of PC9/AB2 cells treated with SU11274 or gefitinib alone or in combination were $(5.38 \pm 1.94) \%, \quad(9.33 \pm 0.98) \%$, and $(15.48 \pm 2.32) \%$ respectively. And the apoptosis rates of integrin beta1inhibited AB2/17-2 cells treated with SU11274 or gefitinib alone or in combination were $(7.8 \pm 1.56) \%$, (26.68 \pm $3.10) \%$, and $(49.72 \pm 6.82) \%$ respectively. It suggested that the combination of integrin beta1-target siRNA and SU11274 could increase apoptosis induced by gefitinib in PC9/AB2 cell line in a synergistic fashion.

\section{Combination of integrin beta1-target siRNA and c-MET kinase inhibitor SU11274 reduced phosphorylation of EGFR and its downstream signals synergistically}

After 30min of treatment with EGF, we investigated the phosphorylation level of EGFR and several of its downstream signaling intermediates (Figure 1E). The synergistic reduction of phosphorylation levels were observed in EGFR, AKT and FAK. Phosphorylation of ERK decreased significantly with c-MET inhibition but not with integrin beta1 inhibition. The results indicated that there was a crosstalk between c-MET and integrin betal, and activation of AKT and FAK were very important for this crosstalk.

\section{Activation of integrin beta1 by FN increased gefitinib resistance}

In our previous research, we found that FN could increase cell adhesion ${ }^{1}$, so we investigated whether or not activation of integrin beta1 by FN could improve survival and increase gefitinib resistance. The IC50 of gefitinib in PC9 and PC9/D6 cells were $(0.042 \pm 0.01) \mu \mathrm{mol} / \mathrm{L}$ and 
A

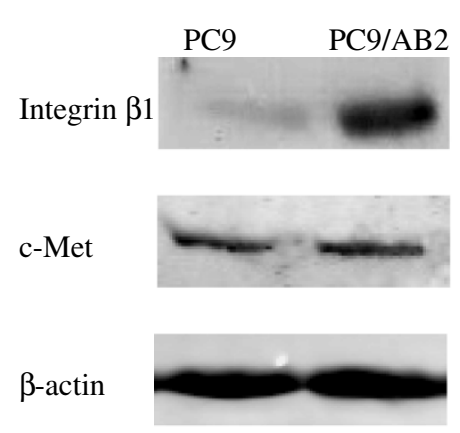

B

Synergistic effect of HGF and fibronectin in PC9 cell line

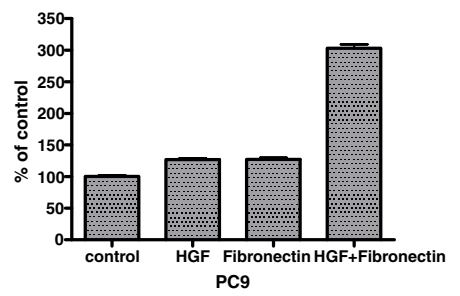

D

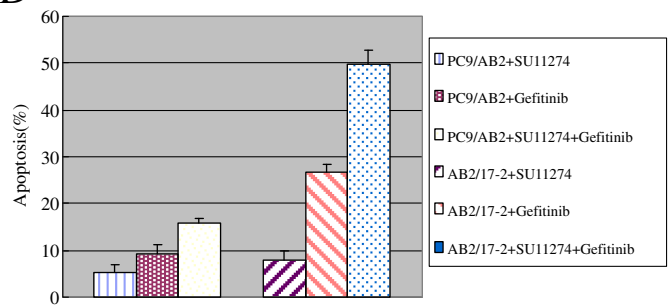

$\mathrm{C}$

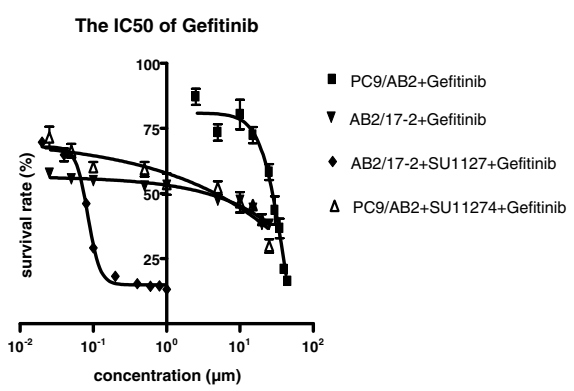

Synergistic effect of HGF and fibronectin in PC9/AB2 cell line

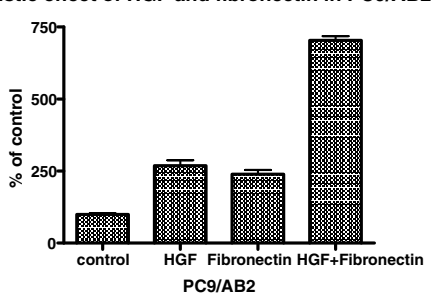

E

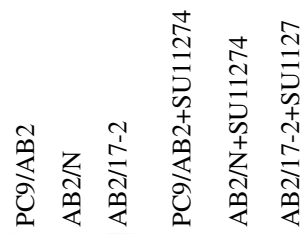

Integrin $\beta$

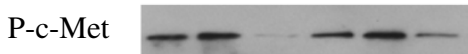

P-FAK Wor

P-EGFR

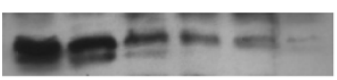

P-AKT

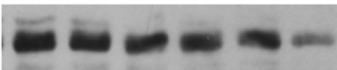

P-ERK

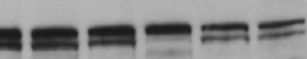

$\beta$-actin

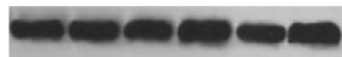

Figure 1 The crosstalk between integrin beta 1 and c-MET. A Western blot analysis showed that integrin beta1 and c-Met co-expressed in PC9 and PC9/AB2 cells. B MTT analysis of proliferative effect of PC9 and PC9/AB2 cells treated with FN and HGF alone or in combination showed a synergistic proliferative effect when FN and HGF combined. C MTT analysis showed that combination of integrin beta1-target siRNA and c-MET kinase inhibitor SU11274 synergized to inhibit proliferation of PC9/AB2 NSCLC cell line. D TUNEL analysis showed that inhibition of c-Met and integrin beta1 concurrently induced apoptosis synergistically. E Western blot analysis showed that phosphorylation of C-Met, EGFR, FAK and AKT were reduced synergistically when c-Met and integrin beta1 were inhibited in PC9/AB2 cells. ${ }^{*} G$ means treatment of gefitinib and P means phosphorylation.

$(9.26 \pm 1.20) \mu \mathrm{mol} / \mathrm{L}$ respectively [1]. The IC50 of gefitinib were $(0.08 \pm 0.03) \mu \mathrm{mol} / \mathrm{L}$ and $(17.50 \pm 4.15) \mu \mathrm{mol} / \mathrm{L}$ in PC9 and PC9/D6 cells when co-treated with FN, respectively (Figure 2A). These data suggested that activation of integrin beta1 by FN could induce gefitinib resistance.
Activation of integrin beta 1 by FN decreased gefitinibinduced apoptosis

To further confirm that the activation of integrin beta1 by FN have some effect on EGFR TKI resistance, we detected the apoptosis of PC9, PC9/D6 cells treated with gefitinib 
with or without FN. The apoptosis rates were $(3.09 \pm$ $1.80) \%,(0.95 \pm 2.13) \%$ in PC9 and PC9/D6 cells, respectively. Their apoptosis rates were $(49.75 \pm 8.60) \%,(12.87 \pm$ $1.53) \%$ when treated with gefitinib. However, they were $(38.09 \pm 7.84) \%,(4.20 \pm 4.29) \%$ when treated with FN and gefitinib, respectively (Figure 2B). The apoptosis were both decreased after treated with FN, but that of integrin beta1overexpressed PC9/D6 cells descended markedly.

\section{Ligand-dependent activation of integrin beta 1 induced c-MET and its downstream signals activation}

After activation of integrin betal by FN, phosphorylation of c-MET, FAK, AKT, and ERK were all increased significantly. It suggested that ligand-dependent activation of integrin beta1 induced c-MET activation and phosphorylation of FAK, AKT, and ERK were related to this effect. So we concluded that ligand-dependent activation of integrin betal could induce EGFR TKI resistance through increasing phosphorylation of cMET and of its downstream signaling pathways: FAK, AKT and ERK (Figure 2C).

\section{Discussion}

In this work, we demonstrate that there is crosstalk between integrin beta1 and c-MET and this crosstalk regulates EGFR TKIs resistance in NSCLC. We provide evidence that integrin beta1/MET crosstalk is a key factor of EGFR TKIs resistance, thus rendering integrin beta1/c-MET a suitable double-target for adjuvant therapy in combination with anti-EGFR agents currently used in clinic.

Although the patients with mutant EGFR display dramatic response to EGFR TKIs, duration of response is typically only 9 to 10 months and then most patients eventually acquire resistance to the agents [20,21], leading to treatment failure. Mechanisms for acquired
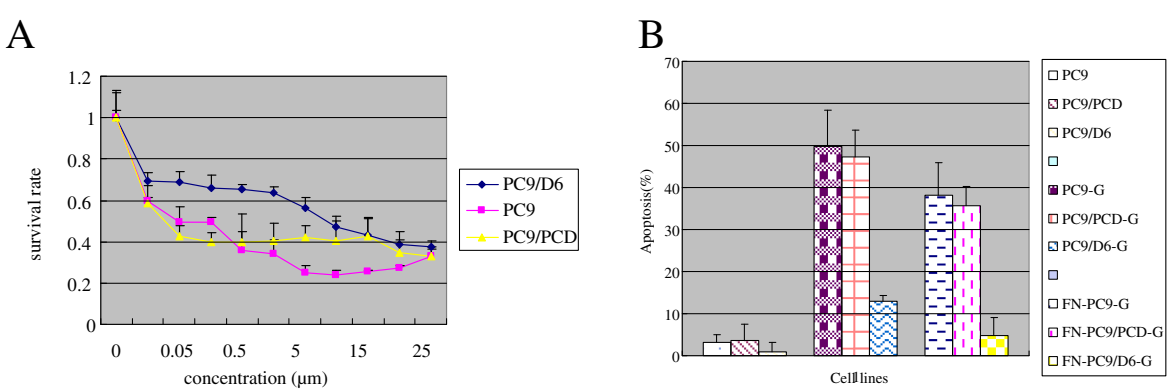

C

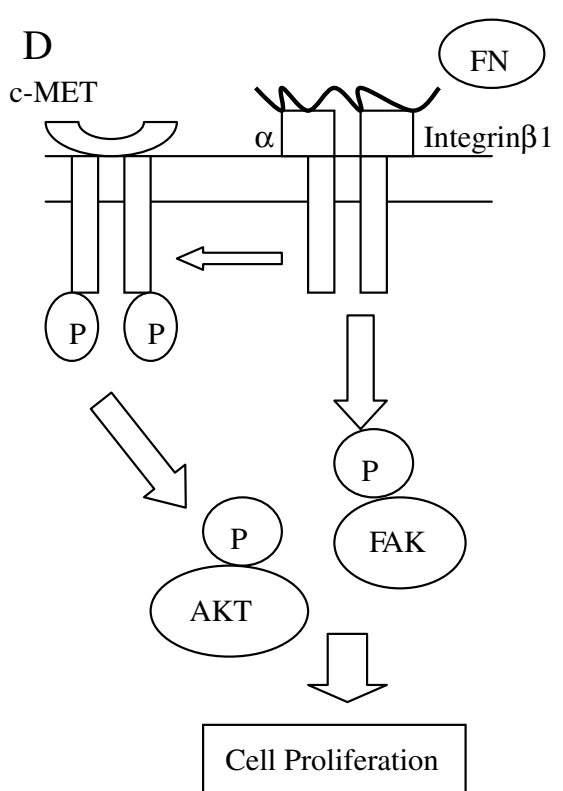

Figure 2 Overexpression and activation of integrin beta1 induce gefitinib resistance via c-MET signaling pathway. A MTT analysis showed that activation of integrin beta1 by FN could induce gefitinib resistance. B TUNEL analysis showed that the apoptosis of PC9/D6 cells were decreased markedly after treated with FN. C Western blot analysis showed that ligand-dependent activation of integrin beta1 could increase phosphorylation of c-Met, FAK, and AKT in PC9/D6 cells. D Overexpression of integrin beta1 induces EGFR TKI resistance through increasing phosphorylation of c-MET and its downstream signals: FAK, AKT. 
resistance to EGFR TKIs have been widely studied. T790M mutation and c-MET gene amplification have been found to be related to acquired resistance to EGFR TKIs in NSCLC [22-24]. Except for the above two mechanisms, others that account for the remaining about $30 \%$ of acquired resistance are still unclear. Some papers showed that integrin betal signaling has been implicated in the progression and metastasis of various cancers, and shown to facilitate resistance to radiation therapy [25] and drug resistance [26]. Moreover, our previous research had confirmed that integrin beta1 was responsible for EGFR TKI resistance.

Integrin beta1, that associates with the adhesion and migration capability of tumor cells and has a key role in the growth and metastasis of tumors, is an important molecular of the adhesion-mediated drug resistance [27-29]. The FN receptor ( $\alpha 5 \beta 1$-integrin) binds to fibronectin to anchor cells and activates non receptor tyrosine kinases, FAK and Src, which play an important role in tumorigenesis by promoting the proliferation and invasion of cancer and endothelial cells [30,31]. In our previous research, we have established the cell lines with stable down- and up- expression of integrin beta1 by transfecting siRNA or integrin beta1 cDNA plasmid into PC9/AB2 cells or PC9 cells, respectively. After down-regulation of integrin beta1, PC9/AB2 cells partially restored sensitivity to gefitinib while up-regulation of integrin beta1 led to resistance of PC9 cells to gefitinib. Expression level of integrin beta1 was negatively correlated with gefitinib sensitivity in these two cell lines. These data identified that integrin beta1 is an important factor of EGFR TKIs resistance. Morello also found that the integrin beta1-silenced cells showed a defective activation of the EGFR signaling cascade, leading to decreased in vitro proliferation, enhanced sensitivity to gefitinib, impaired migration and invasive behavior [5].

Our results showed that both integrin beta1 and c-MET were expressed in these cell lines, and their ligands can enhance cell proliferation synergistically. Importantly, inhibition of both receptors led to growth inhibition and apoptosis, and down-regulation of phosphorylation of molecules in their downstream signal transduction (such as the AKT, FAK pathways) in a synergistic fashion. Ligand-dependent activation of integrin betal induced cMET and it's downstream signals activation (FAK, and $\mathrm{AKT})$. Mitra et al. also reported that inhibition of $\alpha(5) \beta(1)$-integrin decreased the phosphorylation of c-Met, FAK and Src, both in vitro and in vivo. Activation of cMet by its ligand, HGF/SF, or overexpression of a constitutively active FAK in HeyA8 cells could overcome the effect of $\alpha(5) \beta(1)$-integrin inhibition on tumor cell invasion, indicating that $\alpha(5) \beta(1)$-integrin is upstream of c-Met, Src and FAK. Inhibition of $\alpha(5) \beta(1)$-integrin on cancer cells in two xenograft models of ovarian cancer metastasis resulted in a significant decrease of tumor burden, which was independent of the effect of $\alpha(5) \beta(1)$ integrin on angiogenesis [32]. These data shows that there is a crosstalk between integrin beta 1 and c-MET signaling pathways, and it reaches consensus with Beviglia's results that the two signaling pathways, integrin/ECM and c-MET/HGF, cooperate synergistically to induce FAK activation in an adhesion-dependent manner, leading to enhanced cell adhesion and motility [33].

In conclusion, we identified that the crosstalk between integrin beta1 and c-MET via AKT and FAK signaling pathways is very important in EGFR TKI resistance. Our findings identified a new molecular mechanism of EGFR TKIs resistance, which will provide an effective therapeutic intervention of EGFR TKIs resistance.

\section{Competing interests}

None of the authors of this study has a conflict of interest statement.

\section{Authors' contributions}

ZC contributed to concept development and study design. JL performed the experiments and draft the manuscript. Both authors read and approved the final manuscript.

\section{Acknowledgments}

This work was supported by Natural Science Foundation of China (No. 30873023 and 81201706), Foundation of Shanghai Municipal Bureau (20124Y123) and Program for Young Excellent Talents in Tongji University (No. 1511219011). We thank Dr. Ren-Rongzheng (Shanghai University of Traditional Chinese Medicine) for linguistic surport.

\section{Author details}

'Department of Traditional Chinese Medicine, Shanghai Pulmonary Hospital, Tongji University, Medical School, Shanghai 200433, China. ${ }^{2}$ Cancer Institute, Department of Oncology, Shanghai Pulmonary Hospital, Tongji University, Medical School, 507 Zhengmin Road, Shanghai 200433, China.

Received: 14 November 2012 Accepted: 28 January 2013 Published: 13 February 2013

\section{References}

1. Ju L, Zhou C, Li W, Yan L: Integrin beta1 over-expression associates with resistance to tyrosine kinase inhibitor gefitinib in non-small cell lung cancer. J Cell Biochem 2010, 111:1565-1574.

2. Eke I, Deuse Y, Hehlgans SK, Gurtner K, Krause M, Baumann M, Shevchenko A, Sandfort V, Cordes N: $\beta 1$ Integrin/FAK/cortactin signaling is essential for human head and neck cancer resistance to radiotherapy. J Clin Invest 2012, 122:1529-1540.

3. Naci D, Azreq MA, Chetoui N, Lauden L, Sigaux F, Charron D, Al-Daccak R, Aoudjit F: The alpha2beta1 integrin promotes chemoresistance against doxorubicin in cancer cells through the extracellular-signal-regulated kinase (ERK). J Biol Chem 2012, 287:17065-17076.

4. Huang C, Park CC, Hilsenbeck SG, Ward R, Rimawi MF, Wang YC, Shou J, Bissell MJ, Osborne CK, Schiff R: $\beta 1$ integrin mediates an alternative survival pathway in breast cancer cells resistant to lapatinib. Breast Cancer Res 2011, 13:84.

5. Morello V, Cabodi S, Sigismund S, Camacho-Leal MP, Repetto D, Volante M, Papotti M, Turco E, Defilippi P: $\beta 1$ integrin controls EGFR signaling and tumorigenic properties of lung cancer cells. Oncogene 2011, 30:4087-4096

6. Cabodi S, Morello V, Masi A, Cicchi R, Broggio C, Distefano P, Brunelli E, Silengo L, Pavone F, Arcangeli A, Turco E, Tarone G, Moro L, Defilippi P: Convergence of integrins and EGF receptor signaling via $\mathrm{PI} 3 \mathrm{~K} / \mathrm{Akt} / \mathrm{FoxO}$ pathway in early gene Egr-1 expression. J Cell Physiol 2009, 218:294-303. 
7. Velling T, Stefansson A, Johansson S: EGFR and beta1 integrins utilize different signaling pathways to activate Akt. Exp Cell Res 2008, 314:309-316.

8. Wu Y, Chen L, Cao L, Sheng W, Yang BB: Overexpression of the C-terminal $\mathrm{PG}-\mathrm{M} /$ versican domain impairs growth of tumor cells by intervening in the interaction between epidermal growth factor receptor and beta1integrin. J Cell Sci 2004, 117:2227-2237.

9. Kuwada SK, Li X: Integrin alpha5/beta1 mediates fibronectin-dependent epithelial cell proliferation through epidermal growth factor receptor activation. Mol Biol Cell 2000, 11:2485-2496.

10. Faletto DL, Tsarfaty I, Kmiecik TE, Gonzatti M, Suzuki T, Vande Woude GF: Evidence for non-covalent clusters of the c-MET protooncogene product. Oncogene 1992, 6:1149-1157.

11. To CT, Tsao MS: The roles of hepatocyte growth factor/scatter factor and MET receptor in human cancers. Oncol Rep 1998, 5:1013-1024.

12. Stella MC, Comoglio PM: HGF: A multifunctional growth factor controlling cell scattering. Int I Biochem Cell Biol 1999, 12:1357-1362.

13. Christensen JG, Schreck R, Burrows J, Kuruganti P, Chan E, Le P, Chen J, Wang X, Ruslim L, Blake R, Lipson KE, Ramphal J, Do S, Cui JJ, Cherrington $J M$, Mendel DB: A selective small molecule inhibitor of c-MET kinase inhibits c-METdependent phenotypes in vitro and exhibits cytoreductive antitumor activity in vivo. Cancer Res 2003, 21:7345-7355.

14. Sattler M, Pride YB, Ma P, Gramlich JL, Chu SC, Quinnan LA, Shirazian S, Liang C, Podar K, Christensen JG, Salgia R: A novel small molecule MET inhibitor induces apoptosis in cells transformed by the oncogenic TPRMET tyrosine kinase. Cancer Res 2003, 17:5462-5469.

15. Engelman JA, Zejnullahu K, Mitsudomi T, Song Y, Hyland C, Park JO, Lindeman N, Gale CM, Zhao X, Christensen J, Kosaka T, Holmes AJ, Rogers AM, Cappuzzo F, Mok T, Lee C, Johnson BE, Cantley LC, Jänne PA: MET amplification leads to gefitinib resistance in lung cancer by activating ERBB3 signaling. Science 2007, 316:1039-1043.

16. Rahman S, Patel Y, Murray J, Patel KV, Sumathipala R, Sobel M, Wijelath ES: Novel hepatocyte growth factor (HGF) binding domains on fibronectin and vitronectin coordinate a distinct and amplified MET-integrin induced signalling pathway in endothelial cells. BMC Cell Biol 2005, 6:8.

17. McCall-Culbreath KD, Li Z, Zutter MM: Crosstalk between the a2 $\beta 1$ integrin and c-MET/HGF-R regulates innate immunity. Blood 2008, 111:3562-3570.

18. Koizumi F, Shimoyama T, Taguchi F, Saijo N, Nishio K: Establishment of a human non-small cell lung cancer cell line resistant to gefitinib. Int J Cancer 2005, 116:36-44.

19. Puri N, Salgia R: Synergism of EGFR and c-MET pathways, cross-talk and inhibition, in non-small cell lung cancer. J Carcinog 2008, 7:9.

20. Inoue A, Suzuki T, Fukuhara T, Maemondo M, Kimura Y, Morikawa N, Watanabe H, Saijo Y, Nukiwa T: Prospective phase II study of gefitinib for chemotherapy-naive patients with advanced non-small-cell lung cancer with epidermal growth factor receptor gene mutations. J Clin Oncol 2006, 24:3340-3346.

21. Sutani A, Nagai Y, Udagawa K, Uchida Y, Koyama N, Murayama Y, Tanaka T, Miyazawa H, Nagata M, Kanazawa M, Hagiwara K, Kobayashi K: Gefitinib for nonsmall-cell lung cancer patients with epidermal growth factor receptor gene mutations screened by peptide nucleic acid-locked nucleic acid PCR clamp. Br J Cancer 2006, 95:1483-1489.

22. Onitsuka T, Uramoto H, Nose N, Uchida Y, Koyama N, Murayama Y, Tanaka T, Miyazawa H, Nagata M, Kanazawa M, Hagiwara K, Kobayashi K: Acquired resistance of lung adenocarcinomas to gefitinib or erlotinib is associated with a second mutation in the EGFR kinase domain. PLOS Med 2005, 2:73.

23. Kwak EL, Sordella R, Bell DW, Godin-Heymann N, Okimoto RA, Brannigan BW, Harris PL, Driscoll DR, Fidias P, Lynch TJ, Rabindran SK, McGinnis JP, Wissner A, Sharma SV, Isselbacher KJ, Settleman J, Haber DA: Irreversible inhibitors of the EGF receptormay circumvent acquired resistance to gefitinib. Proc Natl Acad Sci USA 2005, 102:7665-7670.

24. Kobayashi S, Boggon TJ, Dayaram T, Jänne PA, Kocher O, Meyerson M, Johnson BE, Eck MJ, Tenen DG, Halmos B: EGFR mutation and resistance of non-small-cell lung cancer to gefitinib. N Engl J Med 2005, 352:786-792.

25. Nam JM, Chung Y, Hsu HC, Park CC: beta1 integrin targeting to enhance radiation therapy. Int J Radiat Biol 2009, 85:923-928.

26. Lesniak D, Xu Y, Deschenes J, Lai R, Thoms J, Murray D, Gosh S, Mackey JR, Sabri S, Abdulkarim B: Beta1-integrin circumvents the antiproliferative effects of trastuzumab in human epidermal growth factor receptor-2 -positive breast cancer. Cancer Res 2009, 69:8620-8628.
27. Wang G, Chen X, Geng Q, Jie L, Gui-Nan L, Yue L: Arsenic Trioxide overcomes cell adhesion-mediated drug resistance through downregulating the expression of beta(1)-integrin in $\mathrm{K} 562$ chronic myelogenous leukemia cell line. Leuk Lymphoma 2010, 51:1090-1097.

28. Emmons MF, Gebhard AW, Nair RR, Baz R, McLaughlin ML, Cress AE, Hazlehurst LA: Acquisition of resistance toward HYD1 correlates with a reduction in cleaved a4 integrin expression and a compromised CAMDR phenotype. Mol Cancer Ther 2011, 10:2257-2266.

29. Estrugo D, Fischer A, Hess F, Scherthan H, Belka C, Cordes N: Ligand bound beta1 integrins inhibit procaspase-8 for mediating cell adhesionmediated drug and radiation resistance in human leukemia cells. PLoS One 2007, 2:69.

30. Mitra SK, Schlaepfer D: Integrin-regulated FAK-Src signaling in normal and cancer cells. Curr Opin Cell Biol 2006, 18:516-523.

31. Caswell PT, Spence HJ, Parsons M, White DP, Clark K, Cheng KW, Mills GB, Humphries MJ, Messent AJ, Anderson KI, McCaffrey MW, Ozanne BW, Norman JC: Rab25 associates with a5 $\beta 1$ integrin to promote invasive migration in 3D microenvironments. Developmental Cell 2007, 13:496-510.

32. Mitra AK, Sawada K, Tiwari P, Mui K, Gwin K, Lengyel E: Ligandindependent activation of c-Met by fibronectin and $\alpha(5) \beta(1)$-integrin regulates ovarian cancer invasion and metastasis. Oncogene 2011, 30:1566-1576.

33. Beviglia L, Kramer RH: HGF induces FAK activation and integrin-mediated adhesion in MTLn3 breast carcinoma cells. Int J Cancer 1999, 83:640-649.

doi:10.1186/1475-2867-13-15

Cite this article as: Ju and Zhou: Association of integrin beta1 and cMET in mediating EGFR TKI gefitinib resistance in non-small cell lung cancer. Cancer Cell International 2013 13:15.

\section{Submit your next manuscript to BioMed Central and take full advantage of:}

- Convenient online submission

- Thorough peer review

- No space constraints or color figure charges

- Immediate publication on acceptance

- Inclusion in PubMed, CAS, Scopus and Google Scholar

- Research which is freely available for redistribution 